Socialist Studies: the Journal of the Society for Socialist Studies 6(1) Spring 2010: 96-124

Copyright (C) 2010 The Author(s)

SPECIAL SECTION

TWENTY YEARS AFTER KANEHSATÀ:KE: REFLECTIONS, RESPONSES, ANALYSES

\title{
From Paintings to Power The meaning of the Warrior Flag twenty years after Oka
}

KAHENTE DOXTATER (HORN-MILLER)

Mohawk Council of Kahnawake. Kahnawá:ke.

\begin{abstract}
As Indigenous peoples we have found it necessary both to react to and to differentiate ourselves from the beliefs, values and practices that have been imposed upon us through colonization. To make our resistance effective, we sometimes use the tools of the dominant society. The Unity Flag in the incarnation that is commonly known as the 'Mohawk Warrior Flag' is one example of this phenomenon. Flown all over the world, it serves as a symbol for the unity of Indigenous peoples, illuminating our discordant relationship with a world that remains dominated by beliefs and values that are alien to us. This paper will introduce a Kanienkehaka perspective on the Flag, reconstructing its symbols and history and illustrating how it carries the message of unity-in-resistance for the various peoples who have turned to it for support in their ongoing struggles with colonialism.
\end{abstract}

\section{Résumé}

En tant que peuples Autochtones nous avons trouvé nécessaire de réagir et de se différencier des croyances, valeurs et pratiques qui nous étaient imposées par la colonisation. Pour rendre notre résistance efficace, nous utilisons parfois les outils de la société dominante. Le Drapeau de l'Unité dans l'incarnation, plus souvent connu sous

Kahente Doxtater (Horn-Miller), Ph.D. (Concordia), works with the Mohawk Council of Kahnawake in recruitment, training and professional development. Her doctoral research focused on expressions of Kanienkehaka (Mohawk) women's identity at Kahnawá:ke. Her creative interests include traditional beading, creative writing and digital photography which she utilizes in her continuing research and writing projects on Indigenous women's issues, Indigenous governance, Indigenous identity, citizenship, and membership. Along with her professional work she volunteers as a creative writing editor, facilitator and instructor for Kahnawake writers. She can be reached at kahente@gmail.com.

Kahente Doxtater (Horn-Miller), Ph.D. (Concordia), travaille avec le Conseil Mohawk de Kahnawake dans le recrutement, la formation et le développement professionnel. Ses recherches doctorales se concentrent sur les expressions de l'identité des femmes de Kanienkehaka (Mohawk) à Kahnawá:ke. Ses intérêts créatifs inclut la joaillerie traditionnelle, l'écriture créative et la photographie numérique qu'elle utilise dans ses recherches et ses projets littéraires sur les questions des femmes Autochtones, de la gouvernance Autochtone, de l'identité autochtone, de la citoyenneté et de l'appartenance. Hormis ses travaux professionnels, elle est bénévole en tant que rédactrice, médiatrice et enseignante en littérature pour des écrivains de Kahnawake. Elle peut être contactée à kahente@gmail.com.

www.socialiststudies.com

ISSN 1918-2821 
le nom de " Drapeau du Guerrier Mohawk » est un exemple de ce phénomène. Flottant partout dans le monde, il sert de symbole de l'unité des peoples autochtones, mettant en lumière nos relations discordantes avec un monde qui reste dominé par des croyances et valeurs qui nous sont étrangères. Cet article introduit une perspective Kanienkehaka sur le Drapeau, reconstruisant ses symboles et son histoire et illustrant la façon dont le Drapeau porte le message de l'unité-en-résistance pour les divers peuples qui se sont tournés vers lui comme soutien dans leurs luttes en cours contre le colonialisme.

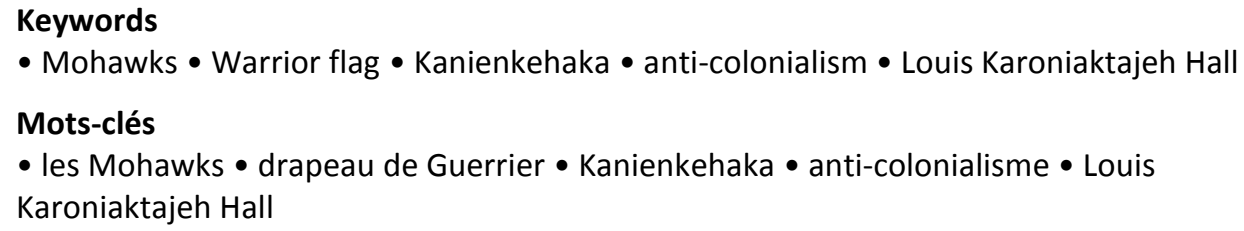

The flag that has become known as the 'Mohawk Warrior Flag' began its existence during the early 1970's, though it did not become widely known until it appeared in mainstream media during the 'Oka Crisis' of 1990. At that time, it fluttered defiantly over the heads of the Kanienkehaka people who were introduced to the public as 'Mohawk Warriors' during a seventyeight day stand-off with the Canadian government. At issue was who had authority to determine and enforce 'the law'. Or, more specifically, could the town of Oka, near Montréal, appropriate a sacred Kanienkehaka burial ground to expand a golf course? The ability of this Flag to provoke comment and action is remarkable. For those who fly it, the Flag means active resistance to a dominant political hegemony. For others who look upon it, it is a painful symbol of anger, hatred, division and racism. Since the Oka Crisis the Flag has shown up all over the world, in such far-flung places as Chiapas, Australia, and Germany, as well as in diverse disputes closer to home such as tenants' rights demonstrations in Toronto, Ontario. Again, the Flag appeared in another prominent Indigenous dispute with the Canadian government. This time the issue concerned control of the lobster fishery at Esgenoopetitj (Burnt Church, New Brunswick, Canada) and the conflict was with the Mi'kmaq. Once again, the core issue concerned what the law was and how this was to be interpreted and implemented. The Flag's use is so wide-ranging and uncontrolled that it would be impossible to catalogue all of the places and circumstances in which it has made an appearance since the Oka Crisis.

My research set out to examine what the 'Warrior Flag' signifies for some of the Indigenous people who use it. My reading could be understood as a semiotic analysis of the Mohawk Warrior Flag as a symbol that 
circulates, that has meaning, and that enters into dialogue with other national symbols, ideologies, and social, political and spiritual structures. My investigation revealed that issues of unity, self-determination and resistance to colonization ran as constant themes through the genesis, use and perceptions of the Flag. For those who seek its support, this Flag serves as a poignant symbol. It represents resistance to assimilation and the assertion of an Indigenous way of looking at the world that is separate and distinct from the ones that the colonial states have attempted to impose. The sense of identity it represents is firmly rooted in Indigenous values, characterized by a connected relationship, to one another and to the land. Both the Kanienkehaka and Mi'kmaq that I spoke to in the course of my research expressed this same understanding about the Flag.

Remarkably, the message of resistance is exactly the message that the Flag's creator hoped it would communicate. Its original name was the 'Unity Flag' and it was designed by Louis Karoniaktajeh Hall, a Kanienkehaka philosopher and activist. Karoniaktajeh was a prolific writer, artist and radical thinker. Some may say he was 'ahead of his time'. Much of his artistic work concerned the assertion of a distinct Kanienkehaka identity. He passed away in 1993 at the age of seventy-six in a relative's house, leaving a prominent legacy in the Warrior or Unity Flag.

Like in the original work where this piece derives, I don't distance myself from the Flag. Signs and symbols of any culture speak to things about that culture that go without saying. Often it takes an insider perspective to translate those signs and symbols in order that they may be understood by others. As a Kanienkehaka woman, my personal connection allow me a certain insight into the history and use of the Flag. Additionally, as an Indigenous scholar, and figurative bridge between our culture and the other, I see it as my job to translate these signs and symbols in a way that makes sense. An accurate translation breeds understanding and dialogue rather than misunderstanding and fear. ${ }^{1}$

\footnotetext{
${ }^{1}$ Mainstream academic formalism is always problematic for Indigenous scholars, making invisible the ways that the 'academic', the personal and the political are always linked. From this perspective the use of 'I' and the explicit mentioning of personal ties is a rejection of the typically problematic distance imposed by a more formally academic style. Maori scholar Linda Tuhiwai Smith's work on Indigenous methodologies promotes the use of cultural protocols, values, and behaviors as an integral part of the research method $(1999,15)$. With this in mind the Iroquoian word for democracy is said to be 'owennasohna' which means 'many voices'. This particular conception of democracy is in line with Iroquoian tradition where true democracy listens to many voices. The concept speaks to the recognition of the collective
} 
In the course of my research, I came to understand that Karoniaktajeh's Unity Flag is a visual representation of the Kaienerekowa, the Great Law of Peace that united the Kanienkehaka with the Oneida, Onondaga, Cayuga and Seneca nations long before European colonists arrived on our shores. Rooted in the laws of nature and meant for all Indigenous peoples of the world, the Kaienerekowa, as we understand it, represents a legally constituted social order that is, and always has been, separate from both the Canadian and the American colonial states. This is the source that inspired the Flag as an expression of our sense of our distinct identity. As Kanienkehaka scholar Gerald Taiaiake Alfred writes,

Values and symbols are drawn from the traditional cultural complex and operationalized as key elements of the reformed identity. The various permutations of the collective identity are understood as forms of nationalism because they maintain traditional cultural boundaries and create group selfidentification as a political community distinct from the state, and consistently committed to the right of self-determination $(1995,182)$

This process of identification is viewed by Alfred as a form of nationalism. It is this deeply rooted sense of our social self, combined with the revitalization of traditional cultural symbols that speaks to the Indigenous nations through the Flag. Strengthening our relationship to creation is the root of the Kaienerekowa and unity is implicit in this relationship. Relating to the natural world on an equal level fosters a sense of unity with it. This is reflected in the Ohén:ton Karihwatéhkwen - The Words That Come Before All Else - or the Thanksgiving Address that we use to open public events. These sentiments were carried into the Kaienerekowa when it was developed to stop blood feuds and unify the five founding nations in peace. The Kaienerekowa turns the philosophy of unity into a legally constituted social order and, because the Unity Flag is a successful visual representation of the philosophy of the Kaienerekowa, the Mi'kmaq people of Esgenoopetitj understood what it was intended to represent without ever having been told its history.

The Flag's genesis in the Kanienkehaka communities and its subsequent use in Esgenoopetitj revealed that issues of unity, selfdetermination and resistance to colonization are integral components to its creation, its use and perception. Until now, this knowledge remained in the oral history of our people and in the original study from which this work derives. The original inspiration for my research on the Flag came

knowledge held by all members of a community. Therefore the use of "I" in this work is my exercising of this concept of 'owennasohna' in the research setting. 
from personal and familial experiences with Louis Karoniaktajeh Hall. After his death, I decided to learn what I could about this man whose work was so influential in our community. I wanted others to be able to see what I saw - that here was an extremely intelligent and singular man who lived alone and devoted much of his life to ensuring Haudenosaunee (Iroquois) survival by teaching about and enhancing our culture.

Originally I wanted to do a biography, but he lived a simple life and there is not much about him in the historical record. I began to realize that his philosophy was more important than the man himself. This has been preserved in his writings and paintings, as well as in the memory of the people who knew him. His philosophical perspective is encompassed in the Unity Flag which is his most prominent legacy. This focus on the Flag itself, rather than on the man, serve as a vehicle for accessing a broader range of reflections that form a part of the oral cultural tradition that I inherited and that Karoniaktajeh dedicated his life to perpetuating.

Like other members of the Kanienkehaka community involved in my study, my life is governed by two frames of reference: the native and the non-native views of the world. As such, my work demonstrates how Indigenous methodologies can be incorporated into the western ethnographic experience of research and writing by incorporating Haudenosaunee philosophy into the fieldwork and writing. Western theoretical considerations within the dialogue engendered by postcolonialism (Tyler 2001; Giddens 1995; Ahmed and Shore 1995), is an area of controversy for Indigenous scholars, but one which may be loosely defined as a debate where the voices of the formerly colonized are gaining strength (Smith 1999). As the situation of Indigenous peoples changes and our relationship with the dominant culture evolves, our true history and culture is becoming more accessible to others.

Karen A. Cerulo's work Identity Designs: The Sights and Sounds of a Nation (1995) serves as a foundation to understanding how the Flag is a poignant symbol of the 'collective conscience' (Durkheim 1933) of a common Indigenous identity. Kanienkehaka identity, and all that underlies it, has remained separate from the one imposed by the state. What is written and spoken about us is not entirely accurate. With this in mind, when the ways and thinking of the Indigenous peoples are understood, then this 'hidden culture' as described by Daniel Corkery in relationship to Ireland, will be revealed (Spicer 1992). This work shows that the Flag is a symbol that serves to remind Indigenous peoples of their culture, connections, and responsibilities to Mother Earth and to one another. 
Central to the ongoing discussions raised by my semi-participant observation are the concepts of self-determination and sovereignty as they relate to Indigenous peoples. These concepts have a multitude of definitions rooted in each Indigenous culture's own perceptions. My work accordingly illustrates how formerly 'hidden' cultures may provide guidelines which will allow colonial administrations to accept governance of Indigenous communities on our own terms in a way that fosters positive relationships rather than disunity. Karoniaktajeh's invention of the Unity Flag is a manifestation of the ideas that nourish this collective movement towards action. In accord with Homi Bhabha's concept of 'hybridity' (Bhabha 1994), new cultural symbols, like the Flag, are inevitable manifestations of the changing relationship between the native and nonnative. Use of the western term 'nation' by Indigenous peoples is similarly a way of removing ourselves from, what is to us, the imagined jurisdiction of the dominant structures.

From our perspective, the idea of human equality was not invented by the United Nations or by the American and French revolutions. The equality of human beings with each other and with the elements of nature is fundamental to the culture from which I gather my strength, my thoughts, and my understanding of the world. The Kanienkehaka have ceremonies and political procedures that reaffirm this perspective in ritual and social practice. A particular relationship with the natural world is what shapes Kanienkehaka philosophy and a tangible manifestation of this, is found in our law, the Kaienerekowa. ${ }^{2}$ The Kaienerekowa is our constitution. It was designed to protect and affirm the independent status of nations and individuals engaged in the quest for a unified approach to mutual problems. The Kaienerekowa contains all the codes of conduct, thought and knowledge needed for people to function, to understand their ceremonies and to maintain a civilized social and political life. These codes are based in nature. So our symbolism is easy to understand and follow. One simply has to look at the world around them to understand the Kaienerekowa in its strength and elusive simplicity.

\footnotetext{
${ }^{2}$ This relationship with the Kaienerekowa is what the western culture would call ideology but the word that we use to describe this is the word 'tsionkwetáh:kwen'. This word, literally translated, means 'the things that we really believe in'. It reflects our connections to one another and to nature, in that these are natural connection, ones that we don't have to think about and analyze. They are from nature and so they just are there to exist with us. So, we don't have to think about whether it is true or not, it just comes from inside, from that very core that is tied to Mother Earth when our mothers place our placenta in the ground after birth.
} 


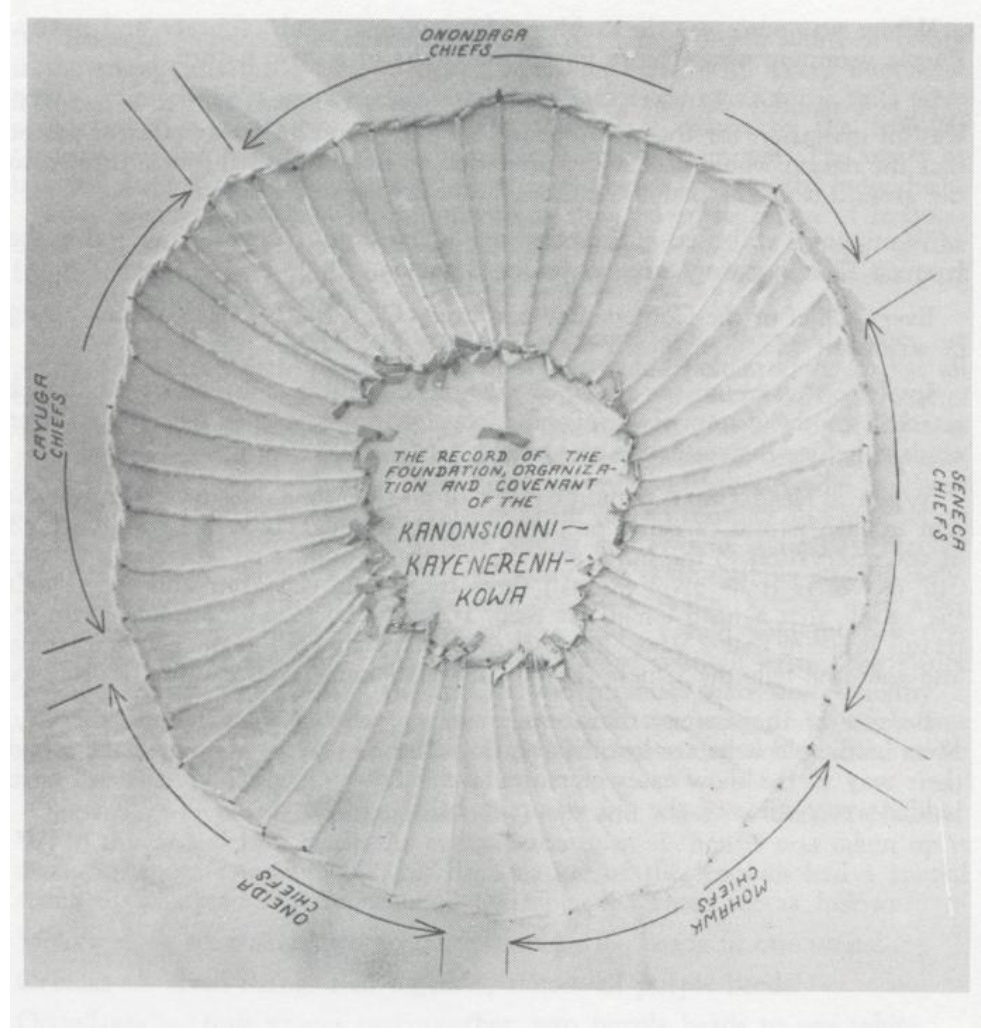

Covenant Circle Wampum (Tehanetorens 1993).
The legend of the founding of the 'Iroquois Confederacy' has been passed down for many generations through oral tradition. Only in the last one hundred years or so has it been recorded in three versions that are widely used. ${ }^{3}$ The Haudenosaunee Confederacy began as a confederation of five nations: Kanienkehaka, Oneida,

3 'Version 1- The Newhouse version, gathered and prepared by Seth Newhouse, a Canadian Mohawk, and revised by Albert Cusick, a New York Onondaga-Tuscarora. This version has been edited and published by Arthur C. Parker of the Rochester Museum in "The Constitution of the Five Nations, or the Iroquois Book of the Great Law" (New York State Museum Bulletin no. 184. Albany, 1916).

'Version 2 - The Chief's Version, compiled by the chiefs of the Six Nations Council on the Six Nations Reserve, Ontario, 1900. This version appears in the "Traditional History of the Confederacy of the Six Nations," edited by Duncan C. Scott (Proceedings and Transactions of the Royal Society of Canada 5. Ottawa, 1911).

'Version 3 - The Gibson version, dictated in 1899 by Chief John Arthur Gibson of the Six Nations Reserve to the late J.N.B. Hewitt of the Smithsonian Institution, and revised by Chiefs Abram Charles, John Buck, Sr., and Joshua Buck, from 1900 to 1914. This version, which is still in manuscript, was translated into English in 1941 by Dr. William N. Fenton of the Bureau of American Ethnology, Smithsonian Institution, with the help of Chief Simeon Gibson.

'A revision and expansion of his own earlier version was dictated by Chief John Arthur Gibson in 1912 to Alexander A. Goldenweiser of the Anthropological Division, Geological Survey, Ottawa, Canada. This is still in Manuscript, untranslated, in the care of Dr. Fenton.' From Wallace 1994, vii. 
Onondaga, Cayuga, and Seneca ${ }^{4}$, organized into a symbolic longhouse structure with the Great Law or Kaienerekowa as its governing constitution. The longhouse was the original dwelling of the Haudenosaunee People and it was designed so it could be extended. The Tuscarora joined the confederacy during the early $18^{\text {th }}$ century. The Covenant Circle wampum represents this unification of the six nations under the principles of the Kaienerekowa.

The six nations of the Haudenosaunee were united for peace and mutual protection under the Kaienerekowa, based in fundamental principle of maintaining peace. Our law provides a method of counselling and decision-making, involving ceremonies and procedures which help people build consensus.

I was able to draw on the philosophy of our law to guide the methodology I used to research the evolution of the Unity Flag and Karoniaktajeh's story. Between November 2001 and June 2003 I conducted ethnographic fieldwork, first with Kanienkehaka from three Kanienkehaka communities surrounded by the Canadian provinces of Ontario and Québec - Akwesáhsne, Kahnawá:ke and Kanehsatà:ke, and then Mi'kmaq people in the community of Esgenoopetitj in New Brunswick.

From those who had known him, I learned that Karoniaktajeh, whose name means 'on the edge of the sky', was a self-educated man who read extensively on many different subjects, especially philosophers such as Plato and Aristotle. ${ }^{5}$ In doing so, he came to his own understanding of the way the Church and the State had collaborated to oppress our people. Karoniaktajeh spent most of his adult life helping people become aware of traditional and social elements in their lives. He used evocative images in his artwork and in his writing to encourage our people to reconnect with our Kanienkehaka identity and heritage. He was the founder and editor of many texts, initiating the Longhouse News and the Warrior Society Newsletter which inspired those who read them to act and react. His work strove to reshape our understanding of history which had become twisted through the distortion and omission of facts. He coined the term 'twistory' to describe the situation, choosing not to accommodate, but rather to

\footnotetext{
${ }^{4}$ In the early 1700's, the Tuscarora nation began the long process of joining the Confederacy as the sixth nation. They went in under the wing of the Seneca who acted as their elder brother and now they sit beside the Senecas when there is a Grand Council. This is why the Confederacy is sometimes called the Six Nations Confederacy.

${ }^{5} \mathrm{He}$ also read the entire Encyclopedia Britannica, which many people remarked upon.
} 
challenge all those who read his writing. He made those who saw his work take a closer look to find what already exists within themselves.

The images he created, both verbally and in his paintings, made it easy for people to see the dimensions of our struggle and to understand the ongoing importance of the Kaienerekowa. People within our community began to understand that our Kanienkehaka perspective was as valid as any other. As a strong proponent of the traditional Longhouse, he concluded that the Kaienerekowa was more than just a spiritual guide. It provided all the mechanisms needed for the Kanienkehaka to behave and live as a nation. All that was needed was for the people to assert their nationhood. One of the most evocative artistic images he created to this end is the Unity Flag, originally conceptualized in a painting sometime in the early 1970 s then drawn as a flag before the Rotiskenrakete, or Men's Society, took the idea and put it to use. No one has really been able to say for sure when Karoniaktajeh first came up with the concept of a flag. In his research, he noticed that nations all over the world have flags and so he felt that the Indigenous peoples should have a flag as well. He may have harboured this idea for as much as ten years before he put it on canvas.

This symbol derived from European heraldic tradition has come to embody the beliefs of Indigenous peoples providing a clear illustration of Homi Bhabha's concepts of mimicry, hybridity and third space. Since the time of contact, mimicry and hybridization have worked both ways with both colonizers and the Indigenous peoples learning from each other though maintaining their parallel existences in Kanienkehaka and settler communities. According to Bhabha, mimicry on the part of the colonized is a complex strategy of reform, regulation and discipline which appropriates the other as it visualizes their power (Bhabha 1994). As the Kanienkehaka moved into the nineteenth century, colonization forced foreign systems and beliefs upon us and a certain amount of mimicry and hybridization were necessary in order to ensure our survival. As a result, Kanienkehaka culture and identity have been preserved, ensuring our marginal presence in North America. Accordingly Kanienkehaka men went off to European wars, they established band council and tribal systems of governance on the reserves following the dictates of the colonial states, and they attempted to gain international support, first at the League of Nations, then at the United Nations. Meanwhile, many took up colonial religions and belief systems, to name just a few of the adaptive strategies used.

Bhabha's concept of hybridity is what occurs when other denied knowledges (of the colonized 'other') enter into the dominant discourse. This reverses the effects of colonialist disavowal of the other by tilting the 
basis of its authority (Bhabha 1994). When aspects of the colonizer's and the colonized societies are brought, coerced, or drawn together, they may repel, mingle, or do a bit of both. What results are cultural changes that manifest themselves in literature, art, music and, taking Bhabha's concept one step further, in politics. It is a place where the production of new forms of cultural meaning occur (Graves 2003) and this is the context in which the Flag was created. As a flag it is a European construct and for it to be displayed so prominently amongst Indigenous peoples is extraordinary. Examples of Kanienkehaka musical, artistic, and literary hybrids abound as the post-colonial period of history looms on the horizon. In an attempt to shake off the metaphorical chains of colonization, Indigenous peoples are finding ways to communicate their current realities. Using various aspects of the dominant culture, we adapt them to our traditions so as to ensure our continued survival as distinct peoples. What results are various hybrids, of which one is the use of a flag to communicate the Indigenous world view. The result is a new world of writing, art, music and politics that can not be compartmentalized according to land, language, and political borders. It speaks to the wider global Indigenous community and situates the Kanienkehaka in a liminal state (Turner 1969; 1988) with regard to what we once were and what we envision ourselves to be. This is defined by Bhabha as the 'third space'.

This third space presents a place where familiar points of reference and meaning are lost. The Kanienkehaka are experiencing the push and pull that characterize this state of being. There is also a constant fear that we will die as a people because that is what many were told as youngsters that we were 'a vanishing race'. 6 According to Bhabha, 'the nonsynchronous temporality of global and national cultures opens up a cultural space - this third space - where the negotiation of incommensurable differences creates a tension peculiar to borderline existences... Hybrid hyphenizations emphasize the incommensurable elements as the basis of cultural identities' (Bhabha 1994, 218) There is thus no mirror in which to look for recognizable concrete forms. This 'third space' challenges the old notion of culture as a homogenizing, unifying force, authenticated by an ancient past, kept alive in the national traditions of the people. The Kanienkehaka experience fits Bhabha's description of the 'third space'. The effects among the Kanienkehaka are an awakened consciousness of history, tradition, culture, community and politics and a resultant series of events such as the move to establish an Independent

\footnotetext{
${ }^{6}$ Personal communication, July 2003.
} 
North American State of Ganienkeh in the 1970s, the Oka Crisis of 1990, and the blockade of a housing development at Caledonia, to name a few. The Kanienkehaka continue to mimic the colonizing society by attempting to use things like the concepts of 'sovereignty' and 'nation'7 to get back to what is believed to be authentic Kanienkehaka classifications and ways of living and doing things. The Flag is part of this dynamic.

Early on in my research I learned that there was more than one version of Flag. In fact there are two flags. The first is known as the 'Unity' or 'Ganienkeh Flag'. It was created in the early seventies during the assertion of sovereignty that led to the establishment of the Independent North American State of Ganienkeh. The second flag is known as the 'Kahnawá:ke Warrior Flag' or 'Mohawk Flag' which emerged during

\footnotetext{
${ }^{7}$ Defining these terms are difficult because the Kanienkehaka world view is different from that of the dominant culture. The dominant language is English and so English terms are used to describe foreign concepts. As such, the Kanienkehaka ideas of sovereignty and nation stem from the principles of non-interference that is one of the oldest principles of international law. It is this principle that shapes the treaty relations that the Haudenosaunee had with other nations and is based on the Two Row Wampum Principle which is symbolized by a belt containing four rows of alternating white and black wampum: 'This belt symbolizes the agreement and conditions under which the Iroquois welcomed the white peoples to this land. You say that you are our Father and I am your son. We say, We will not be like Father and Son, but like Brothers. This wampum belt confirms our words. These two rows will symbolize two paths or two vessels, traveling down the same river together. One, a birch bark canoe, will be for the Indian People, their laws, their customs and their ways. The other, a ship, will be for the white people and their laws, their customs and their ways. We shall each travel the river together, side by side, but in our own boat. Neither of us will make compulsory laws or interfere in the internal affairs of the other. Neither of us will try to steer the other's vessel' (Tehanetorens 1993, 10-11).

Cadwallader Colden (1688-1776) makes reference to this freedom encompassed in this idea of sovereignty in his History of the Five Indian Nations (1902). He states: 'There is not a Man in the Ministry of the Five Nations, who has gain'd his Office, otherwise than by merit; there is not the least Salary, or any Sort of Profit, annexed to any Office, to tempt the Covetous or Sordid; but, on the contrary, every unworthy Action is unavoidably attended with the Forfeiture of their Commission; for their Authority is only the Esteem of the People, and ceases the moment that Esteem is lost. Here we see the natural Origin of all Power and Authority among a free People, and whatever artificial Power of Sovereignty any Man may have acquired, by the Laws and Constitution of a Country, his real Power will be ever much greater or less, in Proportion to the Esteem People have of him' (quoted inVogel 1972, 259). Further, the terms sovereignty and nation are used with reference to indicate the inherent rights of all Indigenous peoples to survive on the land of their ancestors without oppression and persecution and the second term indicates the Kanienkehaka people as a distinct group from Canada.
} 
another assertion of sovereignty in the late 1980's. This is the version that is the most widely known.

Karoniaktajeh's contemporaries believe he spent a long time conceptualizing his idea for the Flag though it is difficult to define the stages of its development for there is no written documentation. The only evidence of his thought processes is found in his other works and drawings. By looking at these, one can find elements that became incorporated in the Flag. One example can be seen in his depiction of The Neverending Longhouse.

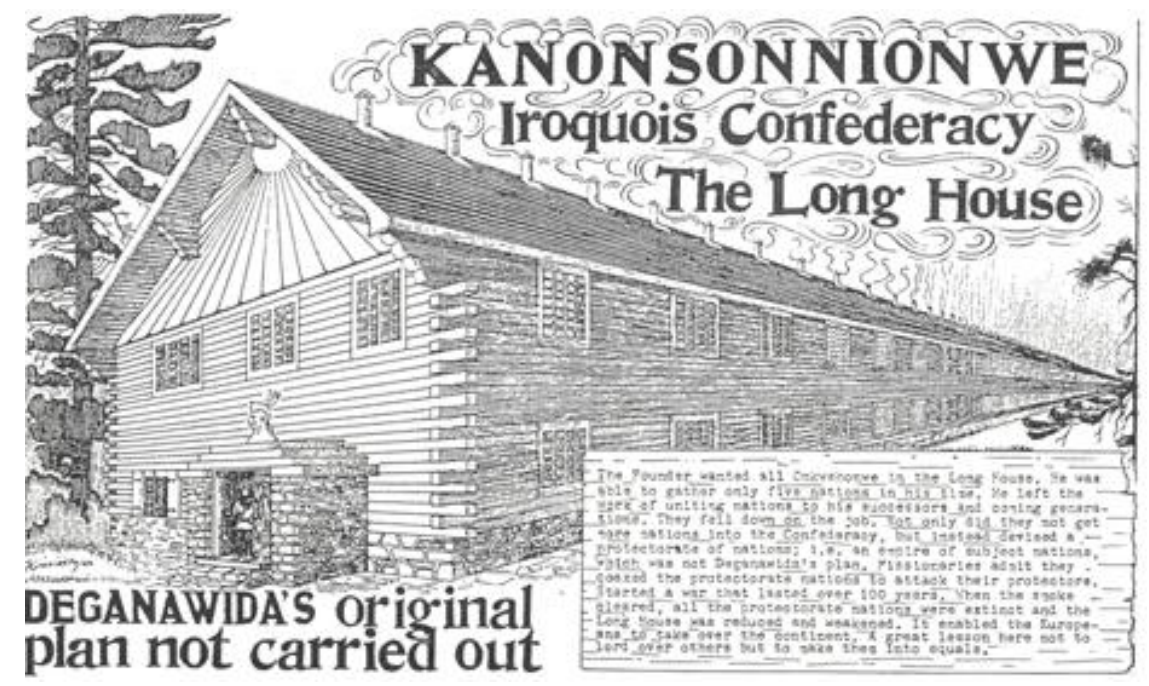

The Neverending Longhouse (Hall, Longhouse News).

Significant elements in this illustration are the sunburst pattern over the door and the perpetual nature of the longhouse building. Both relate to the same elements in the Flag. The image represents the Great Law of Peace spreading out into the world. It is evident that Karoniaktajeh spent many years learning and developing his ideas in other ways that eventually manifested themselves in the Flag we know today. 
Socialist Studies: the Journal of the Society for Socialist Studies 6(1) Spring 2010: 96-124

The first Flag may have originated from this painting.

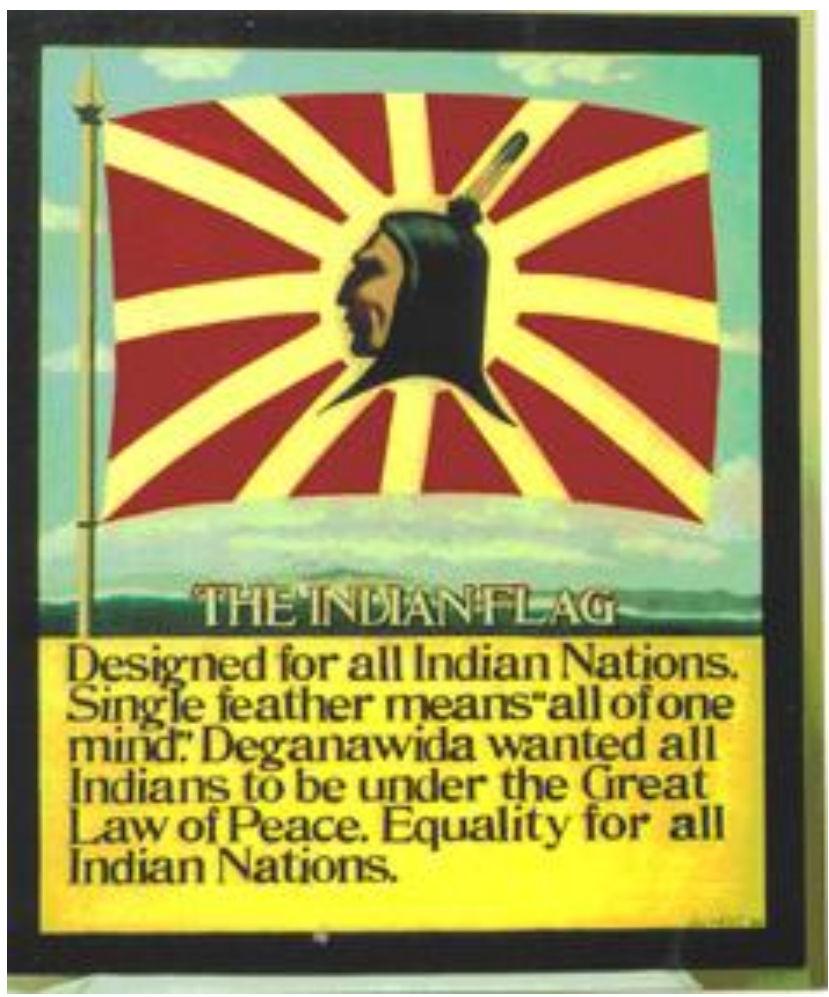

The Indian Flag (Horn Miller, 2003)

This drawing by Karoniaktajeh depicts the first Flag which was used in Ganienkeh.

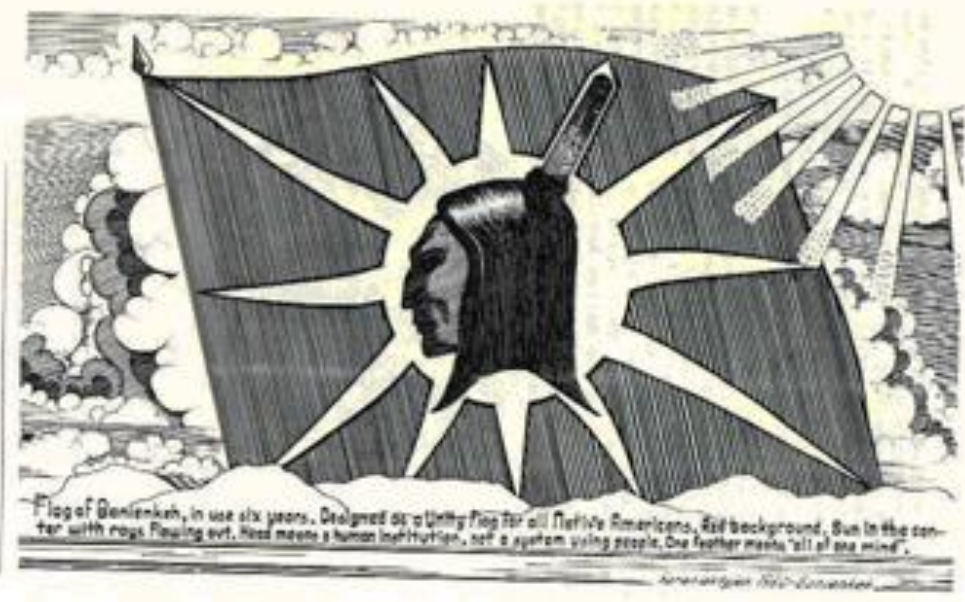

There are slight stylistic differences in the sunburst pattern but essentially they are the same. This final rendition was painted on arm bands worn by the men, on a billboard at the entrance to the Ganienkeh territory and hand-

Flag of Ganienkeh (Hall, n.d.) 
sewn into a flag by non-native women. The hand-made version of the Flag was used by the community of Ganienkeh. It was not changed until the late eighties when another version was created and mass-produced. In 1988, the Kahnawake Rotiskenrakete Warrior Society asked Karoniaktajeh to make a flag specifically for them in response to the organization of a bridge blockade to protest a series of raids on the community's thriving cigarette industry.

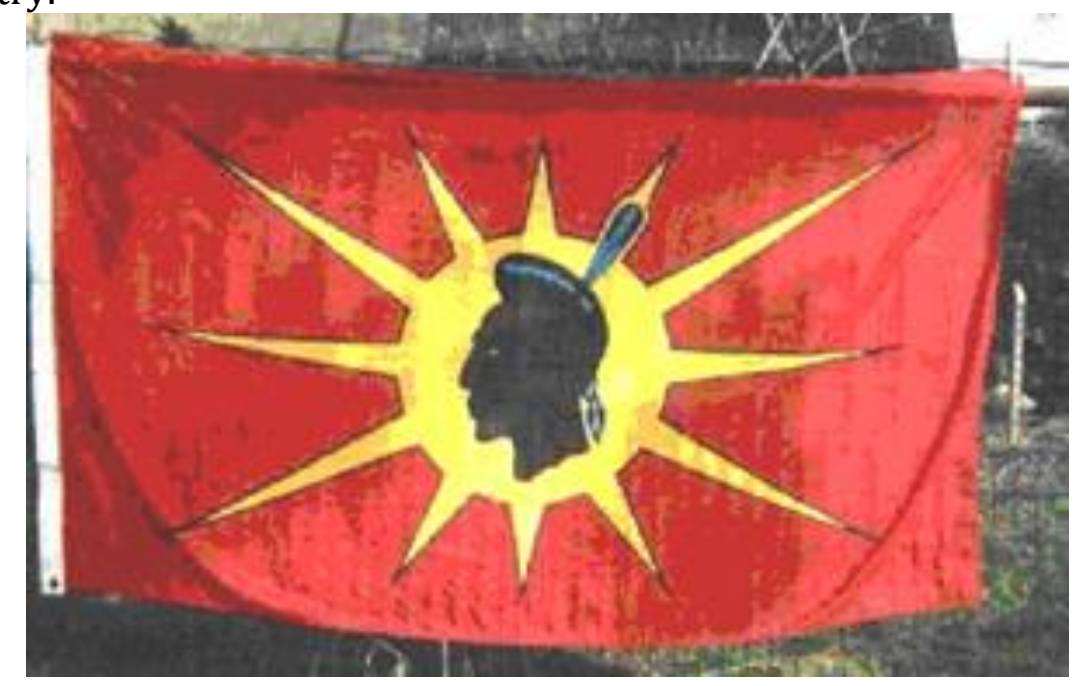

Flag created for Kahnawá:ke Mohawk Warrior Society (Horn-Miller 2003)

The new Flag that Karoniaktajeh designed contained the same symbols as the original Flag. The only difference was in the face and hairstyle. The Warrior head on the Kahnawá:ke flag depicts a traditional Mohawk hairstyle, the scalp lock as seen in the picture. This one is now the one most easily identified and available for sale in flag, patch, pin, and sticker formats.

\section{Elements of the Flag}

The elements of the Flag itself reflect Karoniaktajeh's own interpretation and understanding of the Kaienerekowa and the Kanienkehaka relationship to the natural world. Each symbol not only serves as a reflection of particular laws or wampum but can also be traced to core symbolic elements of Haudenosaunee spirituality and daily life. Karoniaktajeh sought symbolic elements that would be relevant for all 
Socialist Studies: the Journal of the Society for Socialist Studies 6(1) Spring 2010: 96-124

Onkwehonwe 8 by using a design that was not specific to any one Indigenous culture. Thus, the four main symbolic elements of the original Flag presented so long ago in Ganienkeh, are the Indigenous face in profile, the single feather, the sunburst, and the red background.

Profile

The Indigenous profile serves as a reminder to the men of their path in life, their responsibilities to their clan, community and nation enacted through daily life, ceremonies and community protection. Though commonly known as 'warriors', the male role in Indigenous societies is much more comprehensive than the English term implies. Rotiskenrakete the word from the Mohawk language that is translated into English as 'warrior' has a meaning that might more literally be translated as 'he is carrying the burden of peace'.

Hair

The original Flag depicts a profile with long hair falling to the shoulders. All Indigenous nations have particular traditional hairstyles that they use.

Karoniaktajeh sought a symbol that would be identifiable for all so the hair was made to fall at the shoulders. Long dark hair is common amongst Indigenous peoples. What makes the cultures different is how they style it yet, when we take our hair out of our traditional styles at the end of the day, it falls at the shoulders and we all end up looking similar. This aspect, like others included in the Flag was meant to promote a sense of common identity so all would feel able to use the Flag for their own needs, no matter what nation they were from.

The hairstyle on the Kahnawá:ke Mohawk Warrior Flag is different. In times of war, the men of the Haudenosaunee would shave their heads, leaving a round patch at the back of the skull, referred to as a scalp lock. Its purpose may have been to taunt the enemy, teasing him into an attempt to grab and scalp the warrior or it may have made it easier for rapid travel through the trees. Long hair would be more easily snagged and be an impediment to rapid travel needed in times of war. The men would also place ornaments such as silver and feathers in this scalp lock. In preparation, hardwood ash ${ }^{9}$ was rubbed on the bare scalp to remove

\footnotetext{
${ }^{8}$ Onkwehonwe is the work used to describe all Indigenous peoples. Literally translated, it means 'the original people'.

${ }^{9}$ Hardwood ashes are also used in ceremony in where the people and buildings are rid of bad spirits. The ash is rubbed into the hair of the individuals sitting in the center of the longhouse,
} 
stubble and make the hair take longer to grow back. In times of peace the hair was allowed to grow. The Flag introduced at Ganienkeh has long hair. It has accordingly been suggested that perhaps this was another way for the Flag's symbols to promote peace. The stylized version of the scalp lock on the Kahnawá:ke Warrior's Flag indicates, perhaps the need for resistance for it was designed to support the people in a time of tension and conflict.

\section{Direction of Profile}

The direction face by the profile is explained in two ways. First of all, it depends on which way the wind is blowing, thus it has no significance. It is also facing west in all the depictions of it in Karoniaktajeh's drawings and paintings. The significance of the western direction lies in the fact that it is the opposite direction from which people are removed from the Longhouse upon death and buried. Colonialism came to us from the East, so it is also facing away from colonial influences.

\section{Blue Eye}

In the Kahnawá:ke Mohawk Warrior Flag, the Warrior Profile has a blue eye. The meaning of this particular aspect of the Kahnawákke Warrior Flag did not become clear in the interviews. Three theories emerged. The first is that it was a printing error. The second version is that Karoniaktajeh had blue eyes and this was a way of putting himself into the Flag. The third version is that Karoniaktajeh, being realistic, knew that the Kanienkehaka had mixed with non-natives and therefore through successive generations had begun to look different. This takes Bhabha's concept of hybridity even further, underscoring the fact that we have become a hybrid of our former selves. There are, today, many are instances of Kanienkehaka people with red hair, blond hair, blue eyes, and fair complexions, yet they declare themselves to be and are recognized as Kanienkehaka. The traditional sense of Indigenous belonging is based on philosophy and heritage, not blood quantum. Yet our Kanienkehaka ancestors had the black hair, dark eyes and dark skin, characteristic of many Indigenous peoples. As such, it is felt that including the blue eye was in recognition of this fact, and relates to Karoniaktajeh's desire to encourage people to be realistic about their circumstances.

which is then left in for three days. Hardwood ash is also used in the preparation of corn for consumption. The kernels are boiled in the ash and the lye works to remove the husk from the kernel. The corn turns from yellow to red in this process. 
Socialist Studies: the Journal of the Society for Socialist Studies 6(1) Spring 2010: 96-124

Single Feather

The single feather is described in Karoniaktajeh's other work as representing the concept of one mind. This incorporates the Indigenous philosophy of the unity of body, mind, and spirit into a single entity such as the person or people as a whole. Unity is a fundamental aspect of the Kaienerekowa and can be found through the cooperative efforts of diverse people who help each other and respect their differences. Unity does not mean sameness or homogenization. Onkwehonwe know that each of us is unique. Every person has some characteristic that is celebrated and we look to find what each one has brought with them that can help everybody else. A single feather denotes a kind of unity which brings about kariwiio or 'a good mind' and a unity of the person with all of the Indigenous peoples together. As such, the eagle is also a positive symbol for many Indigenous nations. This idea is reflected in the use of its feathers in ceremonies, regalia, and in the burning of natural plants such as sage, sweetgrass, cedar and Indian tobacco which bring our words of thanksgiving up to the Skyworld where our ancestors dwell. It is felt that the eagle has the ability to bring messages to the Skyworld because of its natural ability to soar at great heights.

\section{Sun Rays}

The sun's rays go out in all directions and give life to the plants, animals and humans. It is thought of as the elder brother or rotiskenrakete kowa and plays an important role in the ceremonial, symbolic and spiritual life of the Haudenosaunee. As one Kanienkehaka man stated:

...he [Karoniaktajeh] found the sun played a very important part in all Onkwehonwe peoples culture in the way they looked at life, they way they looked at nature. For us we call the sun our eldest brother. Right across Onkwehonwe country no one ever had anything negative about the sun. He thought that was a positive symbol. ${ }^{10}$

Further, the symbol reminds the man of his responsibility as a rotiskenrakete or carrier of the burden of peace. This symbol also serves as a powerful reminder to the men that they are not merely warriors: they have powerful relationships to one another and to the natural world. This symbol also illuminates the contrast between the relationships that the men and women have with Mother Earth. The women are reminded every day of their relationship by virtue of being women with a spiritual

\footnotetext{
${ }^{10}$ Personal interview, February 2002.
} 
connection to Mother Earth, whereas, the men are reminded of their roles and responsibilities by the sun. The illuminating powers of the sun are also symbolically represented by the light it sheds on the injustices and wrongs that hinder the path or river of life heading towards true peace, power, and righteousness.

The rays of the sun in the Flag reach out in all directions. Recalling Bhabha's hybridity again, the rays in one of the early versions of the Flag followed the pattern of the crosses on the British Union Jack flag. But Indigenous symbolism prevailed and the eventual design also draws on the symbolic white roots of the Tree of Great Peace that, like the sun's rays, reach out in all directions to serve as paths for other nations or individuals to follow back to shelter under the safety of the Kaienerekowa.

\section{Red Background}

The meaning of the red background is not so clear. It is described as representative of redness of blood, which is a life-giving force shared by all. The 'red man' is a common descriptive term for Indigenous peoples who are seen in contrast to the yellow, white and black nations of the Far East, Europe and Africa. Ferocity and anger are often described as in 'seeing red'. Courage and valour are represented by the color red as is power, perhaps because of the color of fire and blood, which , in turn, is a metaphor for life itself. As one Seneca man explained, red is 'kahsastensera, that power. That power that comes from within every single man, woman and child. When that is released, there is no overcoming it.'11 Red represents the power that comes from a collective body of people all with the same intent. When the time comes, that that they must use their power, the Kaienerekowa teaches us to look inward and around us in order to find it. Power, in this sense, is a natural ability. Righteousness exists in every one of us. The red background thus serves as a reminder of the humanity, the life that the Onkwehonwe have been given and so of the responsibilities we have to our mother, the earth for sustaining that life.

\section{Connections}

Because of the power of the symbols chosen by Karoniaktajeh, the Flag has remained essentially the same as it was on the day he unveiled it to the community of Ganienkeh. Since that time it has spread so far, it seems almost incredible. Through careful reflection, this one man

\footnotetext{
${ }^{11}$ Personal interview, February 2002.
} 
succeeded in identifying simple yet powerful symbols that he combined in a Flag that serves as a conduit to the philosophy and culture of the Haudenosaunee and thus to the Indigenous way of thinking. The Flag created by Karoniaktajeh seems to speak to something in many people who want to move forward and take a united stand. This is not the case for most other Indigenous flags. For example, there is only local interest in the flag of the Mi'kmawei Mawiomi or Mi'kmaq Grand Council and a more recently proposed Mi'kmaq flag that comes from a symbol carved in rock. These flags speak to the Mi'kmaq people as a collective and they have not been used by any other Indigenous group. Their symbolic elements speak only to the Mi'kmaq peoples and their meanings are not easily referenced to the cultures of other Indigenous peoples as is the case with the Warrior version of the Unity Flag.

It is worth remembering that, even with slight modifications in the hairstyle, the Flag still holds the same underlying meaning for those who look upon it. The image of the Flag is powerful because it isn't selling seasons tickets, beer, or oil. It functions behind the scenes, providing references to traditions and culture which connect Indigenous peoples to one another and to the natural world.

Karoniaktajeh took images of Onkwehonwe from the popular culture and turned them around to make them powerful as symbols and meaningful to us all as Onkwehonwe. This image may officially belong to the Men's Society of Kahnawá:ke but it is meant for everyone to use. If someone sells a t-shirt or a pin with the image on it, so be it. If someone uses aspects of it to communicate their own message, so be it. Copyright and exclusion are the antithesis to this flag's meaning. Karoniaktajeh would be happy to see that the message of unity is spreading further, as he intended it to.

When the Warrior version of the Unity Flag first came to international prominence in the summer of 1990, during the Oka standoff at Kanehsatà:ke, it flew alongside other Indigenous flags and the symbol of the Haudenosaunee Confederacy, the Hiawatha Belt ${ }^{12}$ depicted in flag form.

12 The Hiawatha Belt is described as this: 'A broad dark belt of wampum of thirty-eight rows, having a white heart or Great Tree in the center, on either side of which are two white squares, all connected with the heart by white rows of wampum shall be the emblem of the unity of the Five Nations. The first of the squares on the left represent the Mohawk Nation and its territory. The second square on the left and the one near the heart, represents the Oneida Nation and its territory. The white heart or tree in the middle represents the Onondaga Nation and its territory, and it also means that the heart of the Five Nations is single in its loyalty to The Great Peace-that the Great Peace is lodged in 
Since that time, the Flag has been sought by others who are caught in David and Goliath struggles, showing up all over the world and continuing to represent the strength that comes through resistance in unity. These concepts form the basis for various demonstrations of Indigenous sovereignty including the establishment of Ganienkeh, the Oka Crisis, Ipperwash, Gustafsen Lake, the Lobster Dispute at Esgenoopetitj (Burnt Church), and the blockade of a housing development at Caledonia, Ontario. Upon cursory examination, these events, involving different people at different times and in different places, all represent unified Indigenous resistance against the Canadian state. They are all Indigenous responses to our loss of land and resources. They all involve showing our strength and a call for assistance from supporters. They are acts that reflect the messages that Karoniaktajeh wrote, drew and painted about.

Because the Flag is used in other places and by other people besides the Kanienkehaka, it is obvious that it communicates the shared meaning and relationships that Indigenous peoples have with one another and the Mother Earth. It is this shared meaning and culture of Indigenous peoples that characterizes them as a bounded entity which can be understood using Benedict Anderson's concept of 'Imagined Community'. It is imagined because 'in the minds of each lives the image of their communion' (Anderson 1998, 6). In accord with this common understanding, Indigenous peoples move freely amongst each other regardless of the lines drawn on colonial maps. They are not tied by man-made boundaries, but rather by their relationship to the land itself.

In order to understand the unifying power of the Flag, it is worth considering why the Flag brings out such strong emotions, both positive and negative. National symbols crystallize the nation's identity by enabling the state structures to tell their citizens who they are. They dictate approaches to what is unfamiliar. As Karen A. Cerulo writes, 'National

the heart-(meaning with Onondaga Confederate Chiefs), and that the Council Fire is to burn there at Onondaga for the Five Nations, and further, it means that the authority is given to advance the cause of peace whereby hostile nations out of the Confederacy shall cease warfare. The white square to the right of the heart represents the Cayuga Nation and its territory and the fourth and last square represents the Seneca Nation and its territory. The two lines extending out from each side of the squares of the belt, from the Mohawk and Seneca Nations, represents the Path of Peace by which other nations are welcomed to travel, to come and take shelter beneath the Great Tree of Peace or join the Iroquois Confederacy. White here shall symbolize that no evil or jealous thoughts shall creep into the minds of the leaders, the Chiefs, while in council under the Great Peace. White, in this case, is the emblem of peace, love, charity and equity and it surrounds and guards the Five Nations' (Tehanetorens 1993, 7-8). 
symbols enable a unique collective "self", distinct from any other entity in the international arena. Via these symbols, political leaders inject the essence of the nation into every citizen' (Cerulo 1995, 15). In western thought, this is what comprises true sovereignty - freedom from external control. In order to be sovereign, And so, in order to feel sovereign, an external 'other' must be defined and labelled as happened through the dynamic that Edward Said defined so well. ${ }^{13}$

Indigenous peoples, by contrast, have a different understanding of this concept. For example, the Kanienkehaka language does not even contain a word comparable to the European concept of 'sovereignty' though a similar idea is encompassed in three words - kahsatstenhsera, meaning 'power', kanikonhriio, meaning 'a good mind', and skennen, meaning 'peace'. These three concepts form the foundation of the Kaienerekowa. It is what gives us our 'sovereignty', expressed by the two row wampum principle ${ }^{14}$, which founded our early treaties with Europeans. The Mi'kmaq, did not have a word for the concept of 'sovereignty' until the Europeans arrived on this continent. There was simply no need for it. Instead, they too used words in combination to communicate similar ideas.As explained by Mi'kmaq historian Stephen Augustine, melgigenowati means 'the strength of our clasping hands together' and tepluotatin means 'we are standing in a circle holding hands until we speak with one voice'. As such, the word that is used to describe sovereignty as it is widely understood in the dominant society is elegeowoti, which means 'the way or method of kings'. A different term is used because it expressed the different relationship that the Mi'kmaq had with the people who came from Europe.

The Flag speaks to Kanienkehaka, Mi'kmaq and other interpretations of sovereignty because it enables people to think of

\footnotetext{
${ }^{13}$ We can't go back to what we were before the Europeans arrived on our shores. We have been taken through so many experiences as a people that colors how we see the world. No longer are we purely Kanienkehaka but we are made up of our many experiences and so we define ourselves always in contrast to the other. Edward Said has described this phenomenon with regard to the view of the exile, 'the essential privilege of exile is to have, not just one set of eyes but half a dozen, each of them corresponding to the places you have been...There is always a kind of doubleness to that experience, and the more places you have been the more displacements you've gone through, as every exile does. As every situation is a new one, you start out each day anew' (Minh-ha 1994, 16). In a sense, the Kanienkehaka are in exile from our traditional homelands and way of life because of colonization. We are always on the outside looking in.

${ }^{14}$ See footnote 7 for a detailed explanation of the Two Row Wampum.
} 
themselves as a unique collective: as Kanienkehaka, Mi'kmaq, Cree, or simply first nations, Indian, or Indigenous. The Flag allows all individuals to relate its meaning in terms of their own cultures. This is why the Mi'kmaq were able to use it to support their own ideas on unity and resistance. The Flag relates directly to feelings and conceptions of unity and strength that can be found in both the Kanienkehaka and Mi'kmaq cultures. This same idea is also communicated in the Mi'kmaq word melgiglosoagan which means 'the strengthening of our words until only one voice is heard'. ${ }^{15}$ In Kanienkehaka language, this is expressed as skanikonhra which means 'one mind'. One mind comes from the Consensual Decision Making Process. Skanikonhra creates the strongest consensus in the world because it draws from the strength that is found in each and every one of the people.

The Flag then, serves to remind the people of their duties as they are codified in the Haudenosaunee Constitution, the Kaienerekowa. If its laws are followed, then peace will be achieved. As Cerulo states, 'national symbols codify the subjective nature of the nation: its moods, desire, and goals - its complexion. They function as modern totems that merge the mythical, sacred substance of the nation with a specified, manifest form, one that is grounded in the everyday experience of sight, sound, or touch. By blending subject and object, national symbols move beyond simple representation of nation. In a very real sense, national symbols become the nation' $(1995,4)$. The Flag then has come to represent the Indigenous collective or 'Imagined Community' that exists in spite of colonially imposed nationalisms.

Despite the minor changes in the design, it is interesting to note that the different versions of the Flag essentially mean the same thing. ${ }^{16}$ Usually, any alteration of the components of a flag will change its meaning. As Cerulo states, 'Study upon study demonstrate structure's centrality to the communication process, as it orders or organizes the various components of symbols. Thus, the syntactic combination of a symbol's components conveys a meaning that differs from that of any single component of the symbol' $(1995,37)$. Each symbol has no inherent meaning, rather it is the culture that injects it with meaning and that meaning can change when it is combined with other shapes or colors and becomes part of a message. In this case, this has not happened. All versions

\footnotetext{
${ }^{15}$ Personal correspondence with Stephen Augustine. June 2003.

${ }^{16}$ Although it is important to note here that the Warrior Flag is the one most readily seen and sold.
} 
of the Flag have retained essentially the same meaning. For the Indigenous observer, the Flag evokes a sense of goodness, pride and the fighting spirit required by those involved in various struggles across the continent. It does not speak exclusively to any one group, leaving the way open for others to join in support and allowing each individual to identify with it in their own way. This freedom inspires and invigorates similar acts of resistance elsewhere which are, in reality, struggles for survival in response to state induced genocide. It stimulates the will to live.

This feeling of linking and shared consciousness was expressed by both Kanienkehaka and Mi'kmaq in Esgenoopetitj. The Flag lends strength to the unity of our common struggles. It makes Indigenous people feel connected as they man their barricades at lonely roadsides in the middle of nowhere or sit on fishing vessels in the middle of the night. There is a simultaneous reaction from desperate peoples all over the world. This type of connection, referred to by the Mi'kmaq, has been described by Emile Durkheim, who observed that 'By uttering the same cry, pronouncing the same word, or performing the same gestures in regard to these [symbolic] objects, individuals become and feel themselves to be in unison' ( quoted in Cerulo 1995, 21).

Further to this idea, national symbols can also become a rallying center. The actions of ritual, honour, statements of purpose and justification bring the symbol to life. This is characteristic of the resistance to the United States and Canada that occurred at Ganienkeh, Oka, Burnt Church, and more recently at Caledonia. As Cerulo states, 'By merging action and symbol, a national collective creates and recreates the ideals embodied by the symbol' $(1995,21)$. The work of Karoniaktajeh created an awareness that fostered a resistance movement that began at Ganienkeh, was carried to Oka and eventually found its way to Burnt Church and Caledonia, among others.

Each time it is used, the Flag continues to raise awareness to the common issues that Indigenous peoples continue to face. As people look upon it, it evokes the memory of where else it has been used before, the strategies, and the outcomes of those situations. When the people of Esgenoopetitj looked at the Flag, it reminded them of Oka, which in turn confirmed the rightness of their actions in their own struggle, and made them feel not so alone. The Flag reminds us that we know that when we stand up for the land and what's on it, it is always the right thing to do.

The Oka Crisis and the Lobster Dispute were both derived from the ideals of unity, resistance, and survival embodied in the Flag because the people were reminded of their natural instructions. Both groups drew on 
the spiritual roots that Indigenous peoples have connecting us to one another and to the land. These can never be destroyed unless we are all killed off and forgotten. The roots lie in the common responsibilities and power that we have as Indigenous people, and therefore we must act to defend the land and the resources for future generations. As Michael Walzer states, the nation 'is invisible; it must be personified before it can be seen, symbolized before it can be loved, imagined before it can be conceived... these images [national symbols] provide a starting point for political thinking' (quoted in Cerulo 1995, 4-5). The Flag, therefore, serves as a symbol of unity for all Indigenous peoples involved in a common struggle for survival. The symbols in it provoke us in ways that speak to particular aspects of our Indigenous cultures but on a more fundamental level it also connects us all. It is a tangible reminder of our common relationship to the natural world.

When I asked the Mi'kmaq at Esgenoopetitj what the Flag meant, the message they related to me was strikingly similar to the message of unity and resistance that the Kanienkehaka had expressed, all without having known about Karoniaktajeh or the Flag's genesis and meaning in the Kanienkehaka communities. Regardless of cultural, territorial, or linguistic differences, the Flag has the ability to speak to different peoples.

As we face common struggles, we unify with a common bond that is rooted in our shared tie to the land. This unification is similar to the way nations lump themselves with their geographic neighbours. What I am proposing with regards to the Flag is that the Indigenous people that use it are identifying themselves with their philosophical neighbours who share the philosophy concerning our tie to the land and our responsibility to maintain our resources and opposition to colonialism. This sense may even be seen in the use of the Flag by non-natives protesting homelessness in places like Toronto.

The Flag's simple design consisting of four elements speaks to fundamental principles found in all Indigenous cultures. Referring again to Anderson's concept of the 'imagined community' this common relationship is what inspires use of the Flag in various circumstances. It is the similarities of world view and relationship to the earth that unite the members of this larger group rather than the definition of physical space represented by territorial boundaries. The Flag represents a meeting place for the minds of the people, a place where they assemble, merge and form a collective entity that overrides the reality of any one individual. It encompasses all areas of social life. The Flag's simple design is easily understood and communicates its message powerfully. 
The struggle that took place during the summer of 1990 put Indigenous resistance and human rights issues on the Canadian and international stage. The symbols that were used to communicate Kanienkehaka identity, those who were involved, and the actions they took to protect land in Kanehsatà:ke have come to symbolize Indigenous resistance in North America. Many, when first asked what the Flag meant, would answer with the word 'Oka'. An awareness and awakening seems to have been communicated to many who viewed the Oka Crisis on television. As a distinctive symbol with vibrant colors, the Flag is hard to miss. Each time a situation occurs that involves Indigenous peoples the Flag is usually present. If you have been in a similar situation, when you see it flying in these contexts you understand what is happening or if you are currently involved in one, you don't feel so alone. The Flag acts as a trigger for the mind. Where the Flag is flying, Indigenous people who view it can relate to the issue more clearly and see their responsibilities as Onkwehonwe. In essence, it serves as a sort of wake-up call which then provokes action.

The responsibilities of the people at Oka were to protect the land for the future, for the seven generations to come. It is this same sense of responsibility to the culture, community, and future generations that is communicated by the Flag. The Oka Crisis and the Lobster Dispute, did just that. Both crisis monopolized the collective, bringing together all factions of the Kanienkehaka and Mi'kmaq communities in a common struggle. The Flag united the people in opposition to a common foe: the Canadian state.

The meaning of the Flag for Indigenous peoples comes down to the simple idea of connections. The Flag, as Karoniaktajeh intended, is a way for us to place ourselves and then talk across cultures. This dialogue has been going on for centuries. The Flag is a modern representation of this phenomenon. The ideas encompassed in the Kaienerekowa exist in many other Indigenous cultures world-wide. Because of this, we all feel a great sense of connection to one another that surpasses the different languages we speak, the diverse songs dances, and ceremonies we perform, or the assorted styles of clothing we wear or foods we eat.

Indigenous peoples have a different kind of spirituality and way of

life. It is one that comes from our connection to our conception and understanding of the natural world, the natural working of cause and effect in our universe, and of our responsibilities to it. There is a highly developed sensitivity to each other's feelings, as well as a high degree of non-verbal communication, which is felt to be a survival mechanism. The belief that all elements of the universe are equally valuable and inextricably related is the centre of the Indigenous worldview and results 
in a very different way of creating knowledge and relating to the world and to other human beings. It concerns the ways in which natural phenomena evoke an emotional response that goes beyond understanding. It is more than what we see, but what we feel. This sensitivity is at the root of our lives and influences everything we do.

In the description of the four main elements of the Flag created by Karoniaktajeh, we saw how they are meant to relate to the culture and ceremonies of the Indigenous peoples. These connections that Indigenous peoples speak of, were well established when the European peoples came to these shores. It was with this in mind that the original peoples attempted to establish relationships with the newcomers. As such, they did not succeed. As a consequence, this relationship with the land has been eroded and it has become a struggle to maintain this tie to the land that is now scarred and damaged.

Our cultural traditions are not just a matter of different names, stories and social events. They are tools for learning about and maintaining our distinct Indigenous identities. They remind us of where our responsibilities lie as Onkwehonwe by enabling us to act out our relationship with the earth as our ancestors had done. For many Indigenous peoples, they see that their responsibilities lie in providing a future for the next seven generations of our children - and yours - by protecting the earth. That is why events like the Oka Crisis and the Lobster Dispute at Esgenoopetitj occur.

In conclusion, there are many more similarities and connections that can be made, but it is unnecessary to do so here. One only has to take a closer look at the world around them, at the people they meet, even in a museum setting, in my case, to understand the connectedness of Indigenous peoples. It goes beyond the colour of our skin, eyes and hair, the material things we share, the knowledge about the plants and animals that we passed to one another. This connection goes deep into Mother Earth, its white roots bring spiritual nourishment to us as we face our daily struggles with such things as social problems, land theft, racism, and cultural survival. It unites us all in our cultures, ideas, ceremonies, world views, and our attempts to alleviate ourselves of the affects of colonialism. It is a connection that will manage to survive because we see its expression in the past and present through things such as the Flag created by Karoniaktajeh. This is but one version. It is meant to inspire awareness and, perhaps, to give others the impetus they need to look deeper within their communities to see what richness is hidden beneath the surface that will tell a remarkable story like that of the Flag. 
It has been over seventeen years since Karoniaktajeh passed away. As I look around my community of Kahnawá:ke, I still see his pervasive influence on my people. At each summer's Echoes of a Proud Nation Powwow, the Mohawk Warrior Flag can be seen everywhere. The powwow is an event that not only brings many nations together to share in the celebration of Indigenous cultures through the dances and songs, but also in the foods. It is a time to renew old friendships and serves as a gathering of the wider family of our common humanity.

Powwows always run the risk of being kitschy with plastic dreamcatchers or fluorescent coloured feathers and 'Made in China' stickers. ${ }^{17}$ But it has its redeeming qualities such as the traditional songs, dances, regalia and use of a wide variety of Indigenous languages. At the most recent powwow, the Mohawk Warrior Flag could be seen flying over a fish and chip stand operated by local people, printed on various items at the Ganienkeh booth, on a man's traditional dance regalia, on car windows and license plates in the parking lot, painted on houses throughout Kahnawá:ke, and for sale on t-shirts, flags, and key chains. Yet, it was not carried in with the official color guard of the Grand Entry Parade that opens the powwow grounds each day.

Irony lies in the fact that the most visible symbol used by Indigenous peoples in the last one hundred years was absent from any official aspect of a powwow originally meant, in part, to commemorate the events and actions of the Kanienkehaka people during the Oka Crisis. This aspect of this annual event has been lost and it has become a wider celebration of Indigenous cultures. This is okay. Whether people realize it or not, the little stickers they put on the back of their car windows, or the fake tattoos they pay a dollar for at the annual powwow each summer are a pervasive symbol of who we are as Onkwehonwe. Its unofficial acceptance shows me that the Flag still belongs to the people, as Karoniaktajeh intended.

On a surface level, the Flag is understood as a symbol of unity and resistance. On another level, it communicates a message that transcends the material world and evokes long developed beliefs and feelings that directly relate to the natural world. Karoniaktajeh's message will last because they are the same 'words' that have been spoken for centuries that communicate to what is inside us. Our actions speak louder than our words. Indigenous peoples everywhere understand that message in the

\footnotetext{
${ }^{17}$ This comment is not meant to belittle China's struggle with colonialism, which, in itself, is another vast topic.
} 
Flag because it speaks to their own past, present and future. Its use in times of crisis, such as the Lobster Dispute at Esgenoopetitj are pervasive examples of the power of the Flag, in its ability to evoke emotion, whether a feeling of pride and unity in an Indigenous person or fear and anger in an east coast fisherman.

Karoniaktajeh was wise to see the need for such a symbol and took a chance. Who dares to make a flag? Nations make flags. The Flag speaks of him and of us as Onkwehonwe. It crosses those linguistic, cultural, and social boundaries and says 'we are here'. I wonder if Karoniaktajeh realized that by running this flag up a pole, he had also replaced an old white one that had been there for years. One that had been there so long we thought it was part of the clouds.

\section{References}

Ahmed, Akbar S. and Cris. N. Shore. 1995. "Is Anthropology Relevant to the Contemporary World?" In The Future of Anthropology. Eds. Akbar S. Ahmed and Cris N. Shore. Atlantic Highlands: Humanities Press International.

Alfred, Gerald R. (Taiaiake). 1995. Heeding the Voices of Our Ancestors: Kahnawake Mohawk Politics and the Rise of Native Nationalism. Toronto: Oxford University Press.

Anderson, Benedict. 1998. Imagined Communities: Reflections on the Origin and Spread of Nationalism, $8^{\text {th }}$ ed. London: Verso.

Bhabha, Homi. 1994. The Location of Culture. London: Routledge.

Cerulo, Karen A. 1995. Identity Designs: The Sights and Sounds of a Nation. Piscataway: Rutgers University Press.

Colden, Cadwallader. 1902. "History of the Five Indian Nations, Which are Dependent on the Province of New York." Excerpted in This Country Was Ours: A Documentary History of the American Indian. Ed. Virgil J. Vogel. New York: Harper \& Row, Publishers, Inc., 1972.

Durkheim, Emile. 1933. The Division of Labor in Society. Glencoe: Free Press.

Giddens, Anthony. 1995. "Notes On The Future of Anthropology." In The Future of Anthropology. Eds. Akbar S. Ahmed and Cris N. Shore. Atlantic Highlands, New Jersey: Humanities Press International, Incorporated.

Graves, B. "Homi K. Bhaba: The Liminal Negotiation of Cultural Difference" in Political Discourse-Theories of Colonialism and Postcolonialism <<http://www.victorianweb.org/post/poldiscourse/bhabha/bhabha2.html >> (Accessed April 1, 2003).

Minh-ha, Trinh. T. 1994. "Other than myself/my other self." In Narrative of Home and Displacements. Eds. G. Robertson et al. New York: Routledge. 
Socialist Studies: the Journal of the Society for Socialist Studies 6(1) Spring 2010: 96-124

Mohawk Nation Office. Statement of the Haudenosaunee Concerning the Constitutional Framework and International Position of the Haudenosaunee Confederacy. Kahnawá:ke: Mohawk Nation Kahnawake Branch. Kanien'kehaka A'onakerahsera, 1982.

Smith, Linda. Tuhiwai. 1999. Decolonizing Methodologies: Research and Indigenous Peoples. Dunedin: University of Otago Press.

Spicer, Edward. H. 1992. "The Nations of a State." In 1492-1992: American Indian Persistence and Resurgence. Ed. Karl Kroeber. Durham: Duke University Press.

Tehanetorens. 1993. Wampum Belts, $3^{\text {rd }}$ ed. Ohsweken: Iroqrafts, Ltd.

Turner, Victor. W. 1969. The Ritual Process: structure and anti-structure. Chicago: Aldine Publishing.

Turner, Victor W. 1988. "Passages, Margins, and Poverty: Religious Symbols of Communitas." in High Points in Anthropology, $2^{\text {nd }}$ edition. Eds. Paul Bohannan and Mark Glazer. New York: McGraw-Hill.

Tyler, Stephen. A. 2001. "Post-Modern Ethnography: From Document of the Occult to Occult Document." In Writing Culture: The Poetics and Politics of Writing Ethnography. Ed. James Clifford and George E. Marcus. Berkeley: University of California Press.

Wallace, Paul A. 1994. White Roots of Peace: The Iroquois Book of Life. Santa Fe: Clear Light Publishing. 